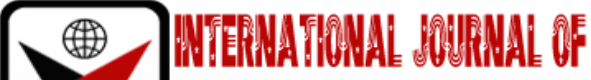

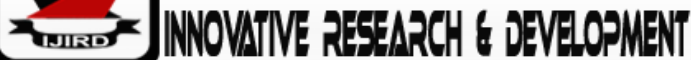

ISSN 2278-0211 (Online)

\section{Organization Transparency and Nation Building of Fast Moving Made in Nigerian Goods Firms in Aba, Abia State, Nigeria}

\author{
Atuo, Eucharia Chinasa \\ Lecturer, Department of Marketing, University of Port Harcourt, Nigeria
}

\begin{abstract}
:
This study examines the relationship between organizational transparency and nation building of fast-moving made in Nigeria goods firms in Aba, Abia State. Organizational transparency is the ability of an organization to be understood by its customers and also being open and honest in all its transactions and operations with customers. Transparency helps organization to provide the needed answers to customer's questions. In line with the population for the study, ten (10) copies of the questionnaire were distributed to ten (10) Registered fast moving made-in Nigeria goods firm each, totalling one hundred (100) and ninety five (96) copies were retrieved,93 copies were filled completely and was also analysed using multiple regression statistical tool.Our analysis revealed a positive and strong significant relationship between disclosure, accessibility, integrity and trust and value system) The study reveals that accessibility and integrity significantly affect value system.). That is to say, disclosure, accessibility, integrity and trust had a positive relationship with nation building. The authors therefore concludes that disclosure to a large extent influences the measure of nation building; vale system positively, accessibility influences value system positively, integrity influences value system positively and trust on the other hand influences value system positively. We further recommend that firms of fast moving made-in Nigeria goods should provide information that are accessible to customers and stakeholders, as well as display in high level of integrity in their business activities.
\end{abstract}

Keywords: Organizational transparency, disclosure, accessibility, integrity, trust, nation building and value system

\section{Introduction}

Nigeria is the largest African country in African continent and the basic goal of Nigeria is to have a nation that is self-reliant in that it can sufficiently tend for itself by producing fast moving consumer goods that will sustain the entire country and also have surplus to export to other countries across the globe.Nigeria as a developing nation is endowed with wealthy, rich and productive resources that are large enough to provide for its citizens and also enhance the economy and GDP through the revenue derived from this endowment. Nigeria is also embedded with so many agricultural produce that can as well feed its citizens. Unfortunately this is not the case of Nigeria and it appears to be historical in Nigeria.

Nigeria produces huge amount of fast-moving consumer goods such as packaged foods, beverages, toiletries, over the counter-drugs, herbal drugs and other consumables, most of these products are perceived as inferior products by Nigerians, especially when the foreign products are readily available in the market. The attitude of Nigerians towards fast moving consumer goods is discouraging and alarming and their general perception is that these goods produced in Nigeria are below standard and interior to foreign goods in terms of performance, quality and durability thereby disregarding and condemning Nigerian locally made goods.Ogumbe (2001), posits that fast-moving consumer goods produced in Nigeria have been stigmatized as 'made-in-Nigeria goods, Igbo or Aba made'goods, and with suchmind-set, the products will not be valued or patronized by Nigerians. He further noted, that will the negative perception of Nigerians toward 'made-inNigeria goods, these firms are likely to lose its craftsmanship, decline in its local production and exportation, drawback in their technological usage and low economic growth.In Nigeria, a huge number of fast-movingconsumer's goods manufacturers have lots of products produced locally and thereis large increase of these local manufacturers in Nigeria and this is as a result of the developmental increase in population and changes in consumer demand (Miebaka, Nwiepe and Kpunee, 2017). Nigeria presently transfers most of its income into importation of foreign goods due to their increasing demand for it (Isah andAliyu, 2017). They posits that Nigeria's food import bills has risen from N112.88 million yearly from 1970-1974 to the sum of N1,964.8 million in 1991. While between year 2000 - 2008, it rose to a total of N80 billion and this was spent only onimportation of grants. Isah and Aliyu (2017), further noted that importation in Nigeria as at 2009 to 2012 stood at $30 \%, 17.4 \%, 21.5 \%$ and $12.9 \%$ respectively, (CBN, 2014). This however indicates that there is reduction in exportation of crop production, while food production only grew marginally.Due to these problems encountered in importation of goods in Nigeria, the government went further to implement a ban on food importation so as to protect and guard manufacturers of fast moving consumer goods against their foreign counterparts (Miebakaet al., 2017).

This however calls for re-examining the frontiers and the role of organizational transparency in Nation building. 
Organizational transparency is the ability of an organization to be understood by its customers and also being open, frank and honest in all of its transactions and operations with customers. Transparency helps organization to provide the needed answers to customer's questions. Winkler (2000), defined transparency could be seen as openness, clarification and accurate information towards the customers.Previous studies operationalized organizational transparency across their various studies, e.g. openness, clarity and accurate information, (Winkler, 2000), Granados, Gupta \& Kauffman (2006), unbiased, complete \& accurate information, (Jordan, Peek \&Rosengren, 2000; Walumbwa et al., 2011) enhanced accessibility and visibility of information (e.g. Kaptein 2008; Madhavan et al., 2005; Pagno\&Roell, 1996; Prat, 2015; Zhio 2004), improved clarity and understandability of information (e.g Flood et al., 1999; McGaughey, 2002; Potosky, 2008, reduced information concealment (e.g, Granados et al., 2010; Larsson et al., 1998), disclosure,, clarity and accurate information (Schnackenberg, 2014).

For the purpose of our study, we adapted the dimensions of previous scholars such as disclosure (Schnackenberg 2014); accessibility (Zhu, 2004), Trust (Lewicki and Bunker, 1996) and Integrity (Armstrong, 2005), because they appear in Literature and having more reach in capturing the fast moving consumer goods manufacturing sector in Nigeria.

Nation building is the ability to achieve sustainable development through employment, openness of manufactures business activities, job creation, creating entrepreneurial opportunities, providing good conditions of service and welfare packages for stakeholders and publics.Nation building is also about providing conducive climate for both foreign and local investors at urban and rural areas (Ahmed-Gamgum, 2014). He further noted that nation building is the process of unifying citizens within and outside the nation, so as to constantly remain politically and economically stable and viable in the future.Nation building is not just about building physical edifice of that nation, but it entails the development of behaviours, values, and norms of a given system (Ahmed-Gamgum, 2014). For the purpose of our study, we adopted the indicator of nation building as value system from the work of Ahmed-Gamgum, (2014). Value system is a unified set of values adopted by an individual, organization or a given society as a standard that guides their behaviour in preferences in all situations or transactions. Value consists of the norms and ethics of a society (Omeje and Eyo, 2008). Value system of a group of customers and stakeholders is a set of beliefs and attitudes that they share in common.Furthermore, it is the set of values according to which people, an organization or society regulate their actions and behavior. Previous studies operationalized organizational transparency across their various studies (e.g. openness, clarity and accurate information Winkler, 2000), Granados, Gupta \& Kauffman (2006), unbiased, complete \& accurate information, Jordan, Peek \&Rosengren, 2000; Walumbwa et al., 2011) enhanced accessibility and visibility of information (e.g. Kaptein 2008; Madhavan et al., 2005; Pagno\&Roell, 1996; Prat, 2015; Zhio 2004), improved clarity and understandability of information (e.g Flood et al., 1999; McGaughey, 2002; Potosky, 2008, reduced information concealment (e.g, Granados et al., 2010; Larsson et al., 1998), disclosure, clarity and accurate information (Schnackenberg, 2014) as their independent variable. In general, however, there is relatively scarce empirical study that measured nation building as value system in relation to the four dimensions of organizational transparency (disclosure, trust, integrity and accessibility) of fast-movingconsumer made in Nigerian goods in Aba, Abia State, Nigeria in a single study.

\subsection{Statement of the Problem}

Nigeria is the largest African country in African continent and the basic goal of any nation is to remain self-reliant and independent. Nigeria as a developing economy is endowed with rich resources that it can cater for itself and rely in the consumption of its products.

However, this is not the case among some local manufacturers of fast moving consumer goods. They produce sub-standard goods, engage in shabby practices in exploiting their customers. They produce goods that are not durable and this has led to dissatisfaction of customers by not patronizing their products. This has also affected their visibility and productivity across foreign nations.

The authors of this paper believes that the application of organizational transparency by these firms will curb the problem of poor value system of local manufacturers of fast moving consumer Nigerian goods in in Aba, Abia State.

It is against this backdrop that our study tries to examine the extent to which organizational transparency influences nation building in Nigeria.

\subsection{Aim/Objectives of the Study}

The aim of the study is to examine the relationship between organizational transparency and nation building of fast moving consumer goods firms in Aba, Abia State.

The specific objectives include the following:

- To examine the relationship between disclosureand nation building.

- To examine the relationship between accessibility and nation building.

- To investigate the relationship between integrity and nation building.

- To determine the relationship between trustand nation building.

\subsection{Research Hypotheses}

The following hypotheses were formulated for the study:

- $\mathrm{HO}_{1}$ :disclosure does not significantly affect value system.

- $\mathrm{HO}_{2}$ : accessibility does not significantly affect value system.

- $\mathrm{HO}_{3}$ :integrity does not significantly affect value system.

- $\mathrm{HO}_{4}$ :trust does not significantly affect value system. 


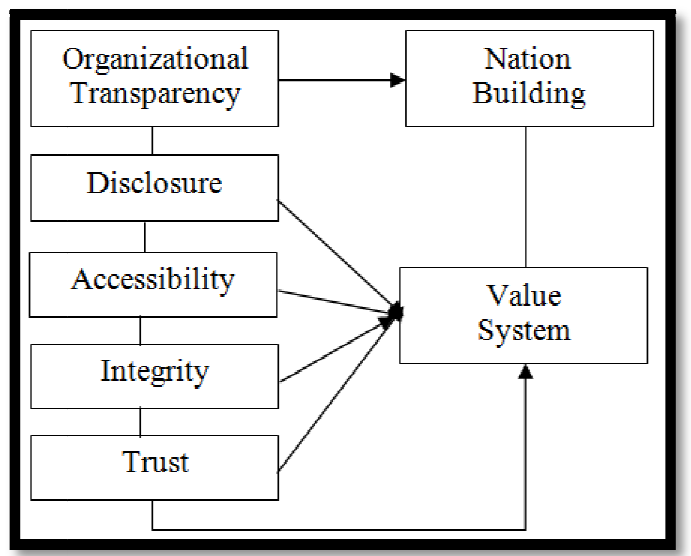

Figure 1: Operational Framework of the Relationship between

Organizational Transparency and Nation Building

Source: Author's Conceptualization (2021)

\section{Literature Review}

\subsection{Theoretical Framework}

The theoretical foundation for the study was drawn from the stakeholder theory of Edward Freeman (1984), who stated that organizational management and focus should be on the maximization of stakeholder's well-being and interest. Stakeholder theory encourages a practical effective and ethical direction to manage a firm in a highly complex and competitive business environment (Freeman, 1984; Freeman, Harrison and Wicks, 2007). Stakeholder theory is a practical theory in that, every organization has to manage its stakeholders whether they are good at managing or not. The theory further noted that stakeholders need to be treated well, because they reciprocate with positive behaviours and attitudes that enhance marketing objectives. Harrison, Bosse\& Philips (2010), posits that the management of stakeholders and customers involves paying attention to the interests and well-being of these stakeholders at a minimum. The theory further advocates treating all stakeholders and customers with fairness, openness, honesty,clarity and also being generous to them.

Stakeholder theory also proposes that treating all stakeholders well and giving them accurate information about the firm and its transactions creates a sort of synergy (Parmar, Freeman, Harrison, Wicks, Purnell \& de Colle, 2010).

\subsection{Organizational Transparency}

Organizational transparency (OT) is the ability for an organization to be open to its stakeholders and ensure that there is accessibility of information by the customers and stakeholders. Winkler (2000), posits that organizational transparency is the extent to which an organization discloses, clarifies and gives efficient information to its stakeholders. Lamming, Caldwell, Harns\& Philips (2001) identified organization transparency as the process of exchanging sensitive information and tacit knowledge in asupply-buyer relationships. Organizational transparency is seen as the method used by organizations to communicate information related to organizational governance and financing to stakeholders (Bhatet al., 2006; Bushman et al.,2004). Rawlins (2008), conceptualized organizational transparency as the perceived quality of information that is conveyed by an organization about its customers. While Awad and Krishman (2006), posits that it is also a perceived quality of information gathered by organization and shared to its external stakeholders. Organizational transparency helps in providing needed answers to customer's questions and also enhances accessibility and visibility of information given to stakeholders and these are the direct construct of transparency which includes: disclosure, accessibility, integrity and trust.

\subsection{Nation Building}

Nation Building is the process of constructing or structuring a national identity through the use of power of the state (Wikipedia, 2013). Ahmed -Gamgum (2014), noted that nation building is not just about building physical structures of a nation, but it entails the development of behaviours, value systems and norms of a given society. Nation building is synonymous with national integration and that national integration refers to bringing culturally and socially discrete people together into a single territorial unit (Ake, 1979). Nation building is also the process of unifying the citizens within and outside of a nation so as to remain financially and politically stable and viable in the long run. Nation building is linked to superior quality product and product availability, that is to say, when the manufacturing firms produces quality madein-Nigeria goods, it therefore bring about patronage because the customer's placed value on the goods produced in Nigeria.

For the purpose of our study, we therefore define nation building as a set of unified values that customers and stakeholders placed on made-in-Nigeria goods, which leads to patronage and repeat purchase of this goods.

Nation building calls for people's interest to be vested at the centre and seen as sovereign. The true necessity for democracy is that power is given into the hands of the people. It is on their action or responsibility that the people can take decisions about their experiences with the manufacturers of fast moving consumer goods in Nigeria and implement law, regulations and decisions according to their needs, requests and conveniences (Shrivastara, 2015). 


\subsection{Measures of Nation Building}

Value system is a unified set of values adopted by an individual, organization or a given society as a standard that guide their actions, behaviour in preferences in all situations or transactions.

The behaviours and attitudes of individuals and citizens of any social system are greatly influenced by their value system (Elendu, 2012). He further noted that values are strong socio-cultural elements that drive and direct an individual or a society. Okolo (1993) stated that value system is seen in the behaviours of people. Nwabuisi, (2000), asserted that value system reflects to how people think and application to the way people think. In Nigeria, the core traditional values placed on the locally made goods have been very low and this has also reduced the motivation to continue producing by the manufacturing firms. Nigerians have successfully engaged in patronizing foreign products and are thereby disregarding'trade in Nigeria' goods.

For the purpose of our study, value system is seen as the priorities that customers and stakeholders attach to specific beliefs and behaviour towards locally made goods.

\subsection{Organizational Transparency and Nation Building}

Nation building is the ability to promote institutions and politics that will provide economic well-being and social equity, (Eme and Onyishi 2014). Nation building is also rebuilding the confidence of both existing and potential customers by satisfying their needs and wants through, information disclosure, accessibility, integrity and trust. Jordan, Peek and Rosengren (2000), posits that a rise in disclosure of information improves the allocation of resources in an organization. Rosengren (1999), further noted that transparency is not a vertical tool for curb crises both in a nation or an organization, but that transparency can act as a tool to reduce the cost of crises in a firm.

Organizational transparency is crucial for all public offices and organization to provide a comprehensive, understandable and reliable picture of their financial performance and objectives so as to help in maximizing investor trust and confidence (Herdman, 2010).

Transparency is about information and knowledge sharing, in other-words, increased transparency enhances increased comprehensibility, coherence and awareness of information that is shared between two or more people (Pagano \&Roell, 1996). Winkler (2000), stated that openness and clarify of information on monetary politics are likely to increase the transparency of communication between economic customers and stakeholders. Burning and Ledinham (2000), conceptualized trust and openness as important indices of how firms and the public should relate with one another. Furthermore, when the organization are sincere, transparent and trustworthy, in their business activities and transactions, it enhances a cordial relationship between the firms and customers, thereby valuing and patronizing madein-Nigeria goods, which in turn increases the profitability of this firms and also upholds made-in-Nigeria goods in high regard.

Given the above propositions, we therefore hypothesized as follows:

- H0:Organizational transparency does not significantly affect value system.

\subsection{Disclosure and Nation Building}

Transparency of the citizens of any nation builds the nation. When citizens and stakeholders are secretive and dubious, it tends to handicap a nation from discharging its responsibilities effectively.

Stakeholders and (customers) have an interest in the processes and outcomes of any given organization and upon which firms depend on them to achieve its business goals (Freeman, 1984; Freeman et al., 2007). Information disclosure is vital in nation building in that customers are being carried along and incorporated by the firms. This tends to build trust and accountability in the customers, thereby patronizing and promoting made-in-Nigeria goods within and outside Nigeria. Treating all customers well and being open to them creates a kind of synergy and satisfaction to the customers, this also motivates the customers to promote manufacturers of made-in-Nigeria goods which thereby increase the customer base and enhance profitability (Parmar, Freeman, Harrison, Wicks, Purnell \& de Colle, 2010; Tantalo and Priem, 2014). Any organization that is conscious of being transparent and honest, wins the loyalty of its customers.

Give the above propositions we hypothesized as follows:

- $\mathrm{H0}_{1}$ :Information disclosure does not significantly affect value system.

\subsection{Accessibility AndNation Building}

Accessibility according to Zhu (2004) is the ability for an individual, organization or a nation to be approachable, available and obtainable. Accessibility of information support, helps customers and stakeholders in the process of decision making (Hossien, Shahri, Phalp and Ali, 2015). Accessibility is also the quality of being reached by customers and stakeholders.

Flood et al., (1999), noted that market information must be clearly, open and accessible to enable market participants to fully value its importance and usefulness.

Comprehensive and reachable information received from a firm enhances customer trust and patronage to the firm's products. Organizational information that is easily accessed and obtainable by customers influences the attitudes, behaviours and values that customers attaches to made-in-Nigeria goods.

Further, this information that is accessed also influences the values the employees place on the organization as regards toinformation transparency (Cording, Harrison, Hoskisson\&Jonsen, 2014; du Luque, Washburn, Waldman \& House, 2008).Clarity and accessibility of information of a given firm, implies that information received and obtained from these firms reduces ambiguity and in turn enhances the customer's value system towards made-in-Nigeria goods, which leads to satisfaction. 
In view of the above,we therefore hypothesized as follows.

- $\mathrm{HO}_{2}$ :Accessibility does not significantly affect value system.

\subsection{Integrity and Nation Building}

Integrity and openness plays a vital role in promoting organizational effectiveness. Kang (2017), posits that integrity requires an inner sense of sincerity and consistency of one's behaviour and words. No nation can develop without a conscious effort to keep to their words and promote honesty in the country. Integrity further means doing the right thing in a reliable way. When manufacturers of made-in-Nigeria goods are consistently doing the right thing, the customers and the public's will be motivated to trust them and uphold them in high esteem, thereby value whatever they say or produce. Integrity is conceptualized as the act of being honest, upright sincere and having a strong moral values and guidance, any nation that does not engage and practice in any of the above indices of integrity is doomed for life. When theseorganizations uphold what is right without changing their words. Customers are bound to patronize them and speak well of them to others.Schottl (2015) stated that for an organization, individual or a nation to achieve integrity and be honest, they have to be whole and undivided. However, when firms of fast moving made in-Nigeria consumer goods, customers, stakeholders, citizens and government are honest and sincere in their transactions and dealings with one another, it fosters and enhances the value of made-in-Nigeria goods in Nigeria, which further leads to nation building. In line with the above propositions, we hypothesized as follows:

- $\mathrm{H}_{3}$ :Integrity does not significantly affect value system.

\subsection{Trust and Nation Building}

Trust is the ability to rely in another person in the phase of risk(UpaMannga, Gulati, Chack, Kaur 2015).In otherwords, it is the act of believing in what someone say or does in any given transaction or relationship. Trust is a central part or focus in all individual relations or business activities between two or more people.

According to Thomas (2009), trust is seen as an expectancy of positive outcome, that is to say, the outcome that an individual receives on the basis of the expected actions of the other individual. Trust enhances any business transactions, and when customers trust a particular firm they tend to be loyal to them, value whatever they say and in turn patronize their products.

Comprehensive and available information received from a firm enhances customer trust and patronage to the firm's product. Any organization or nation that does not build trust and have confidence in their customers, stakeholders and citizens will have themselves to be blamed, because the customers or citizens will devalue and negatively condemn such nation and organization. Trustworthiness therefore breeds loyalty amongst customers and stakeholders, which inturn enhances their values system towards these firms and thus leads to nation building. In view of the above propositions:

We hypothesized as follows:

- $\mathrm{H}_{4}$ :Trust does not significantly affect value system.

\section{Research Methodology}

The study adopted the cross-sectional survey design .The study population consist of 100 top management and middle level staff from ten (10)registered fast moving consumers made-in Nigerian goods firms in Aba, Abia State. (www.Vconnect.com, 2019). Given the accessible population, the study conducted a census study where all units were included in the investigation. The primary instrument for data collection in the study was the structural questionnaire, designed to generate data on the variables of organizational transparency and nation building, while multiple regression was used in testing the hypotheses.

\begin{tabular}{|c|c|c|}
\hline S/N & Firms & No of Questionnaires \\
\hline 1. & Chellarams Plc & 10 \\
\hline 2. & Emeka Stores & 10 \\
\hline 3. & Benco Enterprise Limited & 10 \\
\hline 4. & Consolidated Breweries Plc & 10 \\
\hline 5 & Geymay Industries Limited & 10 \\
\hline 6. & All Fans Bakery & 10 \\
\hline 7. & Poejo Link Services Nigeria & 10 \\
\hline 8 & Jooken Services Nigeria Limited & 10 \\
\hline 9. & Nigerian German Chemicals Plc & 10 \\
\hline 10. & Ristworld Industries and Communication & 100 \\
\hline \multicolumn{2}{|c|}{ Table 1 } \\
\hline
\end{tabular}

\section{Data Analysis and Presentation}

This section is the climax of this study in relation to data analysis; the responses of the respondents, presenting data collected in tables and graphs (figures), analysing the data using multiple regression as highlighted in previous 
section of the study after which discussion of findings follow suit. The researcher relied heavily on data gotten through questionnaires distributed to respondents. One hundred (100) copies of well-structured questionnaires were distributed to the ten (10) studied fast moving made-in Nigeria goods firms in Aba, Nigeria. The information of how they were administered and retrieved were discussed below:

\begin{tabular}{|c|c|c|c|c|}
\hline Firms & Distributed & Retrieved & Not retrieved & Percentage $\%$ \\
\hline All Fans Bakery & 10 & 10 & 0 & 10 \\
\hline Benco Enterprise Ltd & 10 & 10 & 0 & 10 \\
\hline Consolidated Breweries Plc & 10 & 9 & 1 & $9(1)$ \\
\hline Chellarams Plc & 10 & 10 & 0 & 10 \\
\hline Emeka Stores & 10 & 9 & 1 & $9(1)$ \\
\hline Geymay Industries Ltd & 10 & 9 & 1 & $9(1)$ \\
\hline Jooken Service Nigeria Ltd & 10 & 10 & 0 & 10 \\
\hline Nigerian German Chemicals Plc & 10 & 10 & 0 & 10 \\
\hline Peojo Link Services Nigeria & 10 & 9 & 1 & $9(1)$ \\
\hline Ristworld Industries \& Communication & 10 & 10 & 0 & 10 \\
\hline Total & 100 & 96 & 4 & $96(4)$ \\
\hline
\end{tabular}

Table 2: Questionnaire Distribution and Retrieval Source: Survey data, 2021

Some retrieved copies of questionnaires from the respondents were invalid and not suitable for this study. Table 3 discussed further on valid and invalid retrieved questionnaires.

\begin{tabular}{|c|c|c|}
\hline Questionnaire & Frequency & Percentage \\
\hline Distributed & 100 & 100 \\
\hline Retrieved & 96 & 96 \\
\hline Not retrieved & 4 & 4 \\
\hline Retrieved usable & 93 & 96.9 \\
\hline Retrieved not usable & 3 & 3.1 \\
\hline
\end{tabular}

Table 3: Summary of Questionnaire Distribution and Retrieval

Source: Survey data, 2021

From the table above, 100 questionnaires were distributed, 96 which represent $96 \%$ were retrieved, and 4 which represent $4 \%$ were not retrieved. Out of the 96 retrieved 93 which represent $96.9 \%$ were valid and usable, and 3 which represent $3.1 \%$ were invalid and not usable.

\subsection{Hypotheses Testing}

- Decision rule: Reject null hypothesis if $\mathrm{p}<0.05$ and below = Positive relationship; +.1 and above=Negative relationship -0.1. Multiple Regression analysis was used to analyse the stated hypotheses.

Test of Hypothesis One, Two, Three, Four

- $\quad \mathrm{H}_{1}$ :Disclosure does not significantly affect value system

- $\mathrm{HO}_{2}$ : Accessibility does not significantly affect value system

- $\mathrm{HO}_{3}$ :Integrity does not significantly affect value system

- $\mathrm{HO}_{4}$ :Trust does not significantly affect value system

\begin{tabular}{|c|c|c|c|c|c|c|c|c|}
\hline \multicolumn{7}{|c|}{ Model Summary } & & \\
\hline Model & $\mathbf{R}$ & $\begin{array}{c}\mathbf{R} \\
\text { Square }\end{array}$ & $\begin{array}{l}\text { Adjusted } \\
\text { R Square }\end{array}$ & \multicolumn{3}{|c|}{ Std. Error of the Estimate } & & \\
\hline 1 & $.932^{\mathrm{a}}$ & .869 & .856 & \multicolumn{3}{|c|}{9.10657} & & \\
\hline \multicolumn{7}{|c|}{ a. $\quad$ Predictors: (Constant), Disclosure, Accessibility, Integrity, Trust } & & \\
\hline \multicolumn{7}{|c|}{ Coefficients } & & \\
\hline \multirow{2}{*}{\multicolumn{2}{|c|}{ Model }} & \multicolumn{2}{|c|}{$\begin{array}{l}\text { Unstandardized } \\
\text { Coefficients }\end{array}$} & $\begin{array}{c}\text { Standardized } \\
\text { Coefficients }\end{array}$ & $\mathrm{T}$ & Sig. & \multicolumn{2}{|c|}{$\begin{array}{l}95.0 \% \text { Confidence } \\
\text { Interval for B }\end{array}$} \\
\hline & & B & $\begin{array}{l}\text { Std. } \\
\text { Error }\end{array}$ & Beta & & & $\begin{array}{l}\text { Lower } \\
\text { Bound }\end{array}$ & $\begin{array}{l}\text { Upper } \\
\text { Bound }\end{array}$ \\
\hline \multirow[t]{5}{*}{1} & (Constant) & 3.703 & 1.591 & & -1.588 & .135 & -13.404 & 1.998 \\
\hline & Disclosure & .345 & .182 & -.076 & -.390 & .702 & -.486 & .336 \\
\hline & Accessibility & .645 & .211 & .124 & .421 & .680 & -.514 & .765 \\
\hline & Integrity & .153 & .199 & -.127 & -.768 & .455 & -.480 & .227 \\
\hline & Trust & .231 & .285 & -.201 & -.849 & .548 & -.478 & .362 \\
\hline
\end{tabular}

Table 4: Regression Analysis Showing the Effect of Disclosure, Accessibility, Integrity, Trust on Value System. Regression Model: $V S=3.703+[(0.345 D)+(0.645 A)+(0.153 I)+(0.231 T)]$ 


\begin{tabular}{|c|c|c|c|c|c|c|}
\hline \multicolumn{7}{|c|}{ ANOVA } \\
\hline \multicolumn{2}{|c|}{ Model } & Sum of & Df & Mean & $\mathbf{F}$ & Sig. \\
\hline \multirow[t]{3}{*}{1} & Regression & 64067.957 & 4 & 32033.979 & 67.508 & $.000^{\mathrm{b}}$ \\
\hline & Residual & 8066.843 & 89 & 474.520 & & \\
\hline & Total & 72134.800 & 93 & & & \\
\hline \multicolumn{7}{|c|}{ a. Dependent Variable: Value System } \\
\hline & Pred & (Constant), & r & ssibility, I & , Trust & \\
\hline
\end{tabular}

Table 5: Regression Line

$\mathrm{Y}=\mathrm{a}+\mathrm{bX} \mathrm{X}_{1}+\mathrm{bX} \mathrm{X}_{2}+\mathrm{bX} 3+\mathrm{bX} 4$

Where:

$\mathrm{VS}=3.703+[(0.345 \mathrm{D})+(0.645 \mathrm{~A})+(0.153 \mathrm{I})+(0.231 \mathrm{~T})]$

$\mathrm{R}=0.932$

$\mathrm{R}^{2}=0.869$

$\mathrm{F} 4,93=67.508$

$\mathrm{P}$ - value $=0.000$

The result of the multiple regression of the above variables indicated $R=0.932, R^{2}=0.869$ which is equal to $86.9 \%$ and this is the explanatory power of the model used for the study. It means that only $86.9 \%$ variation can be explained by factors within the model used for the study and the remaining 13.1\% can only be explained by other external quantitative and qualitative factors of the model used for the study. The f-ratio (F4, 93=67.508) showed significant effects in existence and this revealed the appropriateness of the model used for the study. The t-ratio showed significant for all the four dimensions of the predictor variable to the present status of value system.

The beta values are the strengths or the extent of contributions to the present position of value system. Integrity made the highest contribution beta value of0.153, Trust came second with 0.231 value, while Disclosure took third position of 0.345 value, while Accessibility came last with a contribution of 0.645 . This means that Accessibility was an insignificant influence to nation building. These results have revealed that the four dimensions of the predictor made significant contribution. Also, the p-value $<0.05$ for the four dimensions of predictor as showed in table 3 . These results mean that the null hypotheses $\left(\mathrm{H}_{0}\right)$ were all rejected except for accessibility, which the alternate hypotheses was accepted as regard to value system.

\section{Discussion of Findings}

This section sought to discuss various findings as regards to analysis of data and findings.

The analysis showed that 100 copies of the questionnaire were distributed to ten (10) selected fast moving madein Nigeria goods firms and 93 returned copies were considered valid for the analysis.

Hypothesis one, two, three and four $\left(\mathrm{H}_{01}, \mathrm{H}_{02}, \mathrm{H}_{03}, \& \mathrm{H}_{04}\right)$ aimed at examining the significant relationship between disclosure, accessibility, integrity and trust and value system. The hypotheses were tested using multiple regression analysis. Our analysis revealed a positive and strong significant relationship between disclosure, accessibility, integrity and trust and value system $\left(R=0.932\right.$ and $\left.R^{2}=0.869\right)$. That is to say, disclosure, accessibility, integrity and trust had a positive relationship with nation building. The findings in this was supported by Cording, Harrison, Hoskisson\&Jonsen, (2014), who posited that information that is accessible influences the values the employees place on the organization as regards to information transparency. Also Jordan, Peek and Rosengren (2000), found a positive influence of disclosure on nation building. They found that a rise in disclosure of information improves the allocation of resources in an organization to an extension......nation building.

\section{Conclusion}

This study examined the relationship of four constructs of organizational transparency (disclosure, accessibility, integrity and trust) on nation building measures (value system) of fast moving made-in Nigeria goods firms in Aba, Nigeria. From the findings, disclosure to a large extent influences the measure of nation building; vale system positively, accessibility influences value system positively, integrity influences value system positively and trust on the other hand influences value system positively. The outcome of the analysis therefore, revealed that the organizational transparency dimensions significantly influence the nation building measure, thus it was established that a positive and significant relationship exist between the dimensions of organizational transparency and the measure of nation building. All the null hypotheses formulated were rejected and alternative hypotheses consequently accepted.

Companies of fast moving consumer goods (FMCG) have a role to ensure that value system is not compromised and this study has revealed that such value system can be made possible through organizational transparency. The attraction of consumers towards made-in Nigerian goods is more valid when they are aware of how the organizations manufactures their goods. 


\section{Recommendations}

The study therefore recommends that firms of fast moving made-in Nigeria goods should provide information that are accessible to customers and stakeholders, as well as display in high level of integrity in their business activities. The study further recommends that companies of fast moving consumer goods (FMCG) should ensure that their business activities and organizational information are accessible to customers and that sincerity and integrity should be their watch word in every business dealings with customers and the society at large, which in-turn enhances the value system of the customers and the nation.

\section{Suggestions for Further Studies}

The researcher suggests that other dimensions of nation building as well as organizational transparency be considered in subsequent studies.

Lastly, studies such as this should be conducted in other geographical area in Nigeria to see the level of the generalization of these work findings. This in essence may lead to discovering and breaking into new knowledge frontiers.

\section{References}

i. Miebaka, A. G. Nwiepe, N. M. \&Kpunee, H. N. (2017). Consumer Behavioural Pattern and Patronage of Made in Nigeria Bags (A survey of Bags Producers in Rivers State, Nigeria). IIARD, International Journal of Economics and Business Management 3 (2).

ii. Isah, B and Aliyu (2017). Impact of law patronage of home- made goods on Nigeria's economic growth. International Journal of Novel Research in Marketing Management and Economics. 4 (2), 62-6.

iii. Walter, R. (1972). How Europe underdeveloped Africa. Bogle, L'ouverture publications, Idershaw Road, London.

iv. Winkler, B. (2000). Which kind of Transparency? On the Need for clarity in monetary policy-making. Working paper no. 26, European central Bank.

v. Bushman, R., Piotroski, J., \& Smith, A. (2004). What Determines corporate Transparency?Journal of Accounting Research,2, 207-252.

vi. Herdman, R. (2001). Testimony concerning recent events relating to Enron corporation, US securities and exchange commission (SEC):<http://ftp.sec.gov/news/testimony/121201+srkh.htm-December 12th.

vii. Granados, N., Gupta, A., \& Kauffman, R. (2005). Transparency strategy in international-based selling. Advances in the economies of information systems.

viii. Granados, N., Gupta, A., \& Kauffman, R. (2006). The impact of IT on market information and transparency: A unified theoretical framework. Journal of the Association for Information systems 7(3),148-178.

ix. Jordan, J., Peek, J., \&Rosengren, E. (2000). The market reaction to the disclosure of supervisory actions: Implications for Bank Transparency. Journal of Financial Intermediation, 3,298-319.

x. Walumbwa, F. O., Luthans, F., Avey, J. J., \&Oke, A. (2011). Authenticity leading groups: The mediating role of collective psychological capital and trust. Journal of Organization Behaviour, 32,4-24.

xi. Kaptein, M. (2008). Developing and testing measures for the ethical culture of organizations: The corporate ethical virtues model. Journal of Organizational Behaviour, 29,123-947.

xii. Madhavan, A., Porter, D., \& Weaver, D. (2005) should securities markets be transparent? Journal of Financial Markets, 3,265-287.

xiii. Pagno, M., \&Roell, A. (1996). Transparency and Liquidity: A comparison of auction and dealer markets with informed trading. Journal of financial markets, 2, 579-611.

xiv. Prat, A. (2005). The wrong kind of transparency: American Economic Review, 95,862-877.

xv. Zhu, K. (2004). Information transparency of business-to-business electronic markets: A game-theoretic analysis. Management sciences, (50),670-685.

xvi. Flood, M., Huisman, R., Koedijk, K., \&Mahieu, R. (1999). Quote disclosure and price discovery in multiple-dealer financial markets. Review of financial studies, 1,37-59.

xvii. McGaughey, S. L. (2002). Strategic interventions in intellectual asset flows. Academy ofManagement Review, 27,248-274.

xviii. Potosky, D. (2008). A conceptual framework for the role of the administration medium in the personnel assessment process, Academy of Management Review, (33),629-648.

xix. Granados, N, Gupta, A., \&Kauttman, R. J. (2008). Designing online selling mechanisms: Information transparency in business-to-consumer markets: Concepts, Framework and Research agenda. Information system research, 21,207-226.

xx. Larsson, R., Bengtsson, L., Henriksson, K., \& Sparks, J. (1998). The inter-organizational learning dilemma: Collective knowledge development in strategic alliances organization science, 9,285-305.

xxi. Lewicki, R. J. \&Bunker, B. B. (1969). Developing and Maintaining trust in Work Relationships. In R. M. Kramer \& T. R. Tyler (Eds.) Trust in organizations: Frontiers of theory and research: 114-139. Thousand Oaks, CA: Sage.

xxii. Bloomfield, R., \& O' Hara, M. (1999). Market Transparency. Who wins and who loses? The review of financial studies, 12 (1),5-35.

xxiii. Williams, C. C. (2008). Toward a taxonomy of Corporate Reporting Strategies. Journal of Business Communication, 45(3),232-264.

xxiv. Finel, B. I., \& Lord, K. M. (1999). The surprising logic of transparency. International studies quarterly, 43,315339. 
xxv. Perotti, E. E., \& Von Thadden, E. (2005). Dominate investors and strategic transparency. Journal of Law, Economics and Organization, 2,76-102.

xxvi. Hosseini, M., Shahri, A. Phalp, K. T. \& Ali, R. (2015). Four Reference Models of Transparency Requirements in Information Systems. Cross mark. Doi.10.1007/500766-017-0265-7. Received:22 June, 2016/?Accepted:6 March 2017.

xxvii. Schnackenberg, A. K. \& Tomlinson, E. C. (2014). Organizational Transparency: A New Perspective on Managing Trust in Organization -Stakeholder Relationships. Journal of Management. 1784-1810.

xxviii. Kang, S. (2017). The true meaning of Integrity. Catalyst @Awaken Group, WEF Young Global Leader, EdTech, MobileTech, Transformation (2017).

xxix. Schottl, L. (2015). The concept of moral integrity and its implications for business, KICG-Forschungspapiere, No. 9, Konstanz institute for corporate Governance (KICG), Hochschule Konstanz, Konstans.

xxx. Ahmed-Gamgum, W. A. (2014). Nigeria at 100 Years: The Process and Challenges of Nation Building. Public Policy and Administration Research. 4(8).

xxxi. Omeje, J. C. and Eyo, M. (2008). Value System and Standard of Education in Nigeria third generation universities: Implications for counselling. A Ph.D Dissertation: Available at https://www.reserachgate.net/publication/27233-6272.Doi:10.4314/afrrev.v212.41048.

xxxii. Churchwell, C. (2003). Corporate Transparency improves for foreign firms in US Markets. Harvard Business school, Working Knowledge series: http://hbsiok.hbs.edu/item/349.html, May 26 ${ }^{\text {th }}$. Accessed, June $20^{\text {th; }} 2019$.

xxxiii. Hodge, F., Kennedy, J., \&Maines, L. (2004). Does search-facilitating technology improve the transparency of financial reporting? The Accounting review, 3, 687-703.

xxxiv. Patel, S., Balic, A., \&Bwakira, L. (2002). Measuring transparency and disclosure at firm level in emerging markets. Emerging markets review, 4,325-37.

xxxv. Freeman, R. E. (1984). Strategic Management: A Stakeholder Approach. Boston: Pitman.

xxxvi. Freeman, R, E., Harrison, J. S. and Wicks, A. C. (2007). Managing for stakeholders Business in the $21^{\text {st }}$ century. Managing for stakeholders: Survival, Reputation and Success. New Heaven: Yale University Press.

xxxvii. Harrison, J. S. Bosse, D. A., \& Philips, R. A. (2010). Managing for stakeholders, stakeholder utility functions and competitive advantage. Strategic management Journal, (31),58-74. (www.interscience whily.com) Do1:10.1002/smj.801.

xxxviii. Parmar, B. L. Freeman, R. E., Harrison J. S., Wicks, A. C., de Colle, S., \& Purnell, L. (2010). Stakeholder Theory: The state of the Art. The Academy of Management Annals. June. 2010. Do1: 10.1080/19416520.2010.495581.

xxxix. Lamming, R. C., Caldwell, N. D., Harrison, D. A., \& Philips, W. (2001). Transparency in supply relationships: Concept ad Practice. Journal of Supply Chain Management, 37(4), 4-10.

xl. Bhat, G. Hope, O., \& Kang, T. (2006). Does corporate governance transparency affect the accuracy of analyst forecasts? Accounting and finance Journal, 46,715-532.

xli. Rowlins, B. L. (2008). Measuring the Relations between Organizational Transparency and Employee Trust. Public relations Journal, 2(2), 1-21.

xlii. Awad, M. F. \&Krishman, M. S. (2006). The personalization privacy paradox: An empirical evaluation of information transparency and the willingness to be profiled online for personalization. MIS Quaterly, 30,13-28.

xliii. Bernstein, E. (2014). The transparency trap. Harvard Business review, 92(10),58-66.

xliv. Wikipedia, (2013). What is Nation Building? Retrieved from www.google.com, on the $10^{\text {th }}$ June 2019.

xlv. Elendu, I. F. (2012). Nigeria's Debased value system at the modern Era: Implications for sports development. Journal of Education and Practice. 3(3).

xlvi. Nwabuisi, E,M. (2002). 'Values and Education' Onitsha: Spiritan publications.

xlvii. Eme, O. I., \&Onyishi, T. O. (2014). Federalism and Nation building in Nigeria. Arabian Journal of Business and Management review (Nigerian chapter). 2(6).

xlviii. Rosengren, E. (1999). Will Greater Disclosure and Transparency Prevent the Next-Banking crisis? In Hunter, W. Kaufman, G., \& Krueger, T. (Eds), The Asian financial crisis: Origins, Implications and Solutions: 369-378. Norwell, MA: Kluwer Academic Publication.

xlix. Bruning, S. D., \&Ledingham, J. A., (Eds) (2000).Organization and key public relationships: Testing the influence of the relationship dimensions in a business -to-business content. In J. A. Ledingham\& S. D. Bruning (Eds). Public relations as relationship management (159-173). Mahwah, NJ: Erlbaum.

l. Tantalo, C., \&Priem, C. L. (2014). Value creation through stakeholder synergy. Strategic management Journal. Do1:10:1002/smj. 2337.

li. Cording, M., Harrison, J. S. Hoskisson, R. E. \&Jonsen, K. (2014). Walking the talk: A multi-stakeholder exploration of organizational authenticity employee productivity and post-merger performance. Academy of management perspectives, 28(1), 38-56.

lii. De Luque, M. A., Washburn, N., Waldman, D. A. \& House, R. J. (2008). Unrequited profit: How stakeholder and economic values relate to subordinate perception of leadership and firm performance. Administrative science quarterly, 53,626-654.

liii. Ogumbe, O. J. (2001). Challenges and issues in Nigerian business of the $20^{\text {th }}$ century African recovery press, Lagos, Nigeria.

liv. Armstrong, E. (2005). Integrity, Transparency and Accountability in public Administration: Recent Trends, Regional and International Developments and Emerging Issues. Economic \& Social Affairs (United Nations). 
Iv. Nicolaou, A. I. \&Mcknight, D. H. (2006). Perceived Information quality in data exchanges: Effects on risk, trust and intention to use. Information systems research, 17,332-351.

lvi. Pirson, M., \& Malhotra, S. (2011). Foundations of Organizational trust. What matters to different stakeholders? Organization science, 22, 1087-1104. 